Prepared in cooperation with the Triangle Area Water Supply Monitoring Project Steering Committee

\title{
Quality of Surface-Water Supplies in the Triangle Area of North Carolina, Water Year 2009
}

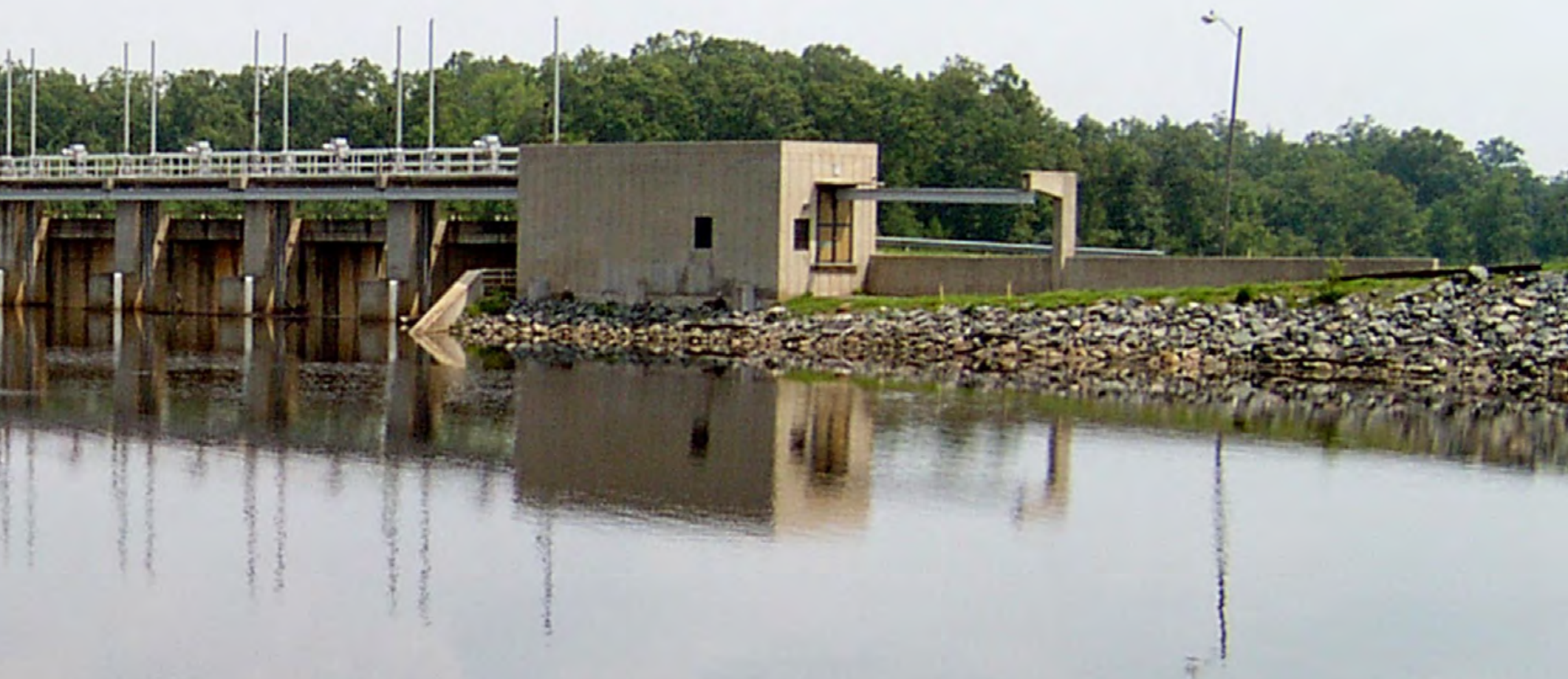

Open-File Report 2014-1192

U.S. Department of the Interior

U.S. Geological Survey 
Cover: Little River Reservoir at dam near Bahama, North Carolina. Photograph by Cassandra Pfeifle. 


\section{Quality of Surface-Water Supplies in the Triangle Area of North Carolina, Water Year 2009}

By C.A. Pfeifle, M.J. Giorgino, and R.B. Rasmussen

Prepared in cooperation with the Triangle Area Water Supply Monitoring Project Steering Committee

Open-File Report 2014-1192 


\title{
U.S. Department of the Interior SALLY JEWELL, Secretary
}

\section{U.S. Geological Survey Suzette M. Kimball, Acting Director}

\author{
U.S. Geological Survey, Reston, Virginia: 2014
}

For more information on the USGS - the Federal source for science about the Earth, its natural and living resources, natural hazards, and the environment—visit http://www.usgs.gov or call 1-888-ASK-USGS.

For an overview of USGS information products, including maps, imagery, and publications, visit http://Www.usgs.gov/pubprod

To order this and other USGS information products, visit http://store.usgs.gov

Any use of trade, firm, or product names is for descriptive purposes only and does not imply endorsement by the U.S. Government.

Although this information product, for the most part, is in the public domain, it also may contain copyrighted materials as noted in the text. Permission to reproduce copyrighted items must be secured from the copyright owner.

Suggested citation:

Pfeifle, C.A., Giorgino, M.J., and Rasmussen, R.B., Quality of surface-water supplies in the Triangle area of North Carolina, water year 2009: U.S. Geological Survey Open-File Report 2014-1192, 13 p.,

http://dx.doi.org/10.3133/ofr20141192.

ISSN 2331-1258 (online) 


\section{Contents}

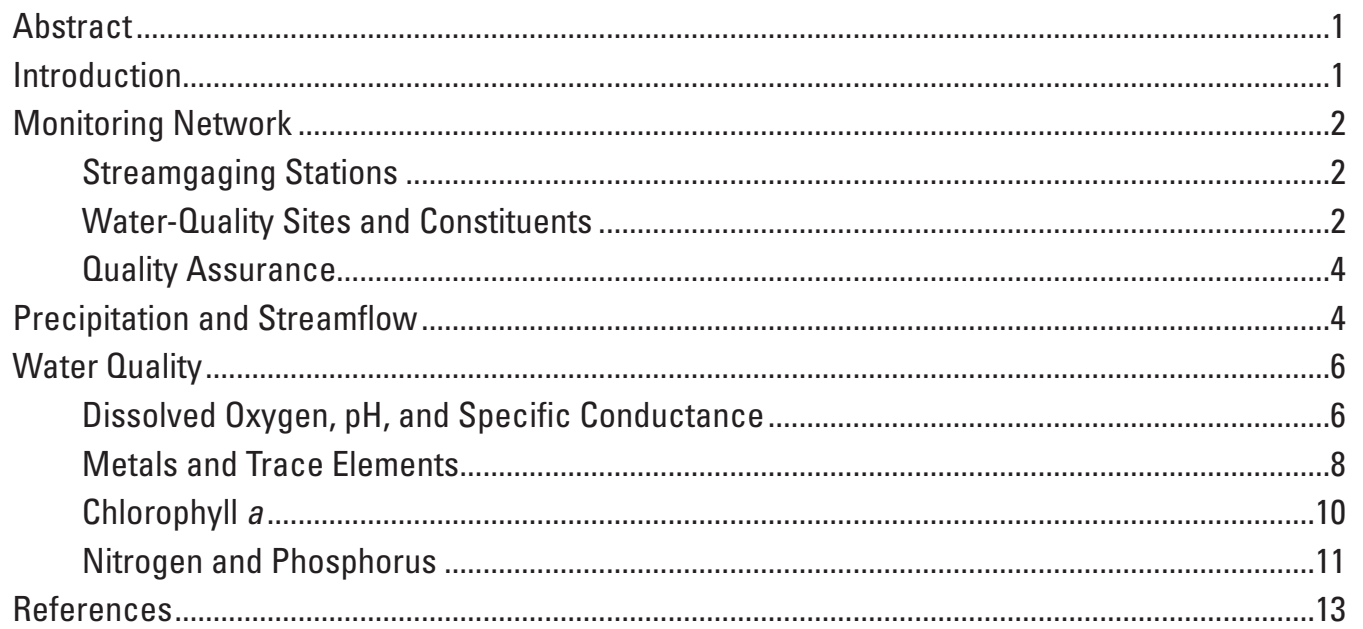

\section{Figures}

1. Map showing location of Triangle Area Water Supply Monitoring Project data-collection sites in the upper Cape Fear and Neuse River Basins, North Carolina ...

2-5. Graphs showing-

2. Monthly precipitation at the Raleigh-Durham International Airport, North Carolina, October 2008 through September 2009...

3. Palmer Hydrological Drought Index values for the Northern Piedmont and Central Piedmont climate divisions of North Carolina, October 2008 through September 2009

4. Annual runoff measured from October 2008 through September 2009 and long-term mean for the period of record at ten U.S. Geological Survey streamgaging stations in the Triangle area of North Carolina.

5. Seven-day average streamflow, in cubic feet per second, at site 1, Eno River at Hillsborough in the Neuse River Basin, and site 19, Haw River near Bynum in the Cape Fear River Basin, for the period January 2008 through 2009

6-8. Maps showing -

6. Sites in the Triangle area of North Carolina with one or more dissolved-oxygen concentration less than 5 milligrams per liter and dissolved-oxygen percent saturation values greater than 110 percent, 0 ctober 2008 through September 2009

7. Sites in the Triangle area of North Carolina with one or more concentration of unfiltered iron greater than 1,000 micrograms per liter, unfiltered manganese greater than 200 micrograms per liter, unfiltered mercury greater than 0.012 microgram per liter, and unfiltered copper greater than 7 micrograms liter, October 2008 through September 2009

8. Sites in the Triangle area of North Carolina with one or more concentration of chlorophyll a greater than 40 micrograms per liter, October 2008 through September 2009 
9. Graphs showing concentrations of total nitrogen (ammonia plus organic nitrogen and nitrate plus nitrite) and total phosphorus at sites in the Triangle Area Water Supply Monitoring Project study area, October 2008 through September 2009

Tables (Excel files available at $h t t p: / / p u b s . u s g s . g o v / o f r / 2014 / 1192 /)$

1. Water-quality and streamflow monitoring sites for the Triangle Area Water Supply Monitoring Project, October 2008 through September 2009.

2. Summary of water-quality results for sampling sites in the Triangle Area Water Supply Monitoring Project, October 2008 through September 2009.

\section{Conversion Factors and Definitions}

Inch/Pound to SI

\begin{tabular}{|c|c|c|}
\hline Multiply & By & To obtain \\
\hline \multicolumn{3}{|c|}{ Length } \\
\hline inch (in.) & 25.4 & millimeter $(\mathrm{mm})$ \\
\hline mile (mi) & 1.609 & kilometer $(\mathrm{km})$ \\
\hline \multicolumn{3}{|c|}{ Flow rate } \\
\hline cubic foot per second $\left(\mathrm{ft}^{3} / \mathrm{s}\right)$ & 0.02832 & cubic meter per second $\left(\mathrm{m}^{3} / \mathrm{s}\right)$ \\
\hline
\end{tabular}

Specific conductance is given in microsiemens per centimeter at 25 degrees Celsius $\left(\mu \mathrm{S} / \mathrm{cm}\right.$ at $\left.25^{\circ} \mathrm{C}\right)$.

Concentrations of chemical constituents in water are given either in milligrams per liter (mg/L) or micrograms per liter $(\mu \mathrm{g} / \mathrm{L})$.

\section{Abbreviations}

$\begin{array}{ll}\text { MCL } & \text { maximum contaminant level } \\ \text { NCDWQ } & \text { North Carolina Division of Water Quality } \\ \text { SDWR } & \text { secondary drinking-water regulation } \\ \text { TAWSMP } & \text { Triangle Area Water Supply Monitoring Project } \\ \text { USGS } & \text { U.S. Geological Survey }\end{array}$




\title{
Quality of Surface-Water Supplies in the Triangle Area of North Carolina, Water Year 2009
}

\author{
By C.A. Pfeifle, M.J. Giorgino, and R.B. Rasmussen
}

\begin{abstract}
Surface-water supplies are important sources of drinking water for residents in the Triangle area of North Carolina, which is located within the upper Cape Fear and Neuse River Basins. Since 1988, the U.S. Geological Survey and a consortium of governments have tracked water-quality conditions and trends in several of the area's water-supply lakes and streams. This report summarizes data collected through this cooperative effort, known as the Triangle Area Water Supply Monitoring Project, during October 2008 through September 2009. Major findings for this period include:
\end{abstract}

- Annual precipitation was approximately 20 percent below the long-term mean (average) annual precipitation.

- Streamflow was below the long-term mean at the 10 project streamgages during most of the year.

- More than 7,000 individual measurements of water quality were made at a total of 26 sites - 15 in the Neuse River Basin and 11 in the Cape Fear River Basin. Forty-seven water-quality properties and constituents were measured.

- All observations met North Carolina water-quality standards for water temperature, $\mathrm{pH}$, hardness, chloride, fluoride, sulfate, nitrate, arsenic, cadmium, chromium, lead, nickel, and selenium.

- North Carolina water-quality standards were exceeded one or more times for dissolved oxygen, dissolved oxygen percent saturation, chlorophyll $a$, mercury, copper, iron, manganese, silver, and zinc. Exceedances occurred at 23 sites -13 in the Neuse River Basin and 10 in the Cape Fear River Basin.

- Stream samples collected during storm events contained elevated concentrations of 18 water-quality constituents compared to samples collected during non-storm events.

- Concentrations of nitrogen and phosphorus were within ranges observed during previous years.
- Five reservoirs had chlorophyll $a$ concentrations in excess of 40 micrograms per liter at least once during 2009: Little River Reservoir, Falls Lake, Cane Creek Reservoir, University Lake, and Jordan Lake.

\section{Introduction}

The Triangle area, located within the upper Cape Fear and Neuse River Basins, is one of the most rapidly developing areas of North Carolina. Population growth continues to increase demands for water from public suppliers, the majority of which draw water from streams and lakes in the region. Growth also brings the threat of greater loads of pollutants and new contaminant sources which, if not properly managed, could adversely affect water quality.

For more than 20 years, the Triangle Area Water Supply Monitoring Project (TAWSMP) has tracked waterquality conditions and long-term trends in many of the area's water-supply lakes, rivers, and tributaries. The project has progressed in phases, allowing for flexibility in the monitoring network and partners and for timely response to emerging water-quality concerns (http://nc.water.usgs.gov/projects/ triangle/overview.html) (U.S. Geological Survey, 2012c). Objectives of the project for 2009 were to

- Extend the existing water-quality database for nutrients, sediment, major ions, and metals and trace elements to track spatial variations in water quality, loads to reservoirs, and long-term water-quality trends.

- Continue monitoring at tributary sites during high-flow events to increase the understanding of constituent concentrations and loads during extreme hydrologic conditions.

- Investigate the occurrence of mercury in water and sediment.

- Maintain a network of 10 continuous streamgaging stations in the study area. 
Pursuant to an agreement with several local governments, the U.S. Geological Survey (USGS) monitors hydrologic conditions and collects water samples up to six times a year at 31 sites, depending on site location and hydrologic conditions. Water temperature, dissolved oxygen, $\mathrm{pH}$, and specific conductance are measured, and analyses are performed to determine concentrations of nutrients, metals and trace elements, major ions, and total organic carbon at all sites. In addition, suspended-sediment concentrations are measured at stream sites. Chlorophyll $a$ is analyzed at lake sites. One additional site consists only of a streamflow gage. Continuous streamflow is recorded at almost all of the stream sites and is funded through the TAWSMP and other USGS programs. The USGS is responsible for data quality assurance, analysis, and interpretation, providing the data to the public and maintaining the data in perpetuity. Funding for the project is provided by local government partners (see sidebar) and by the USGS Cooperative Water Program (http://water.usgs.gov/ coop/) (U.S. Geological Survey, 2012a). The Triangle J Council of Governments provides organizational support services for the TAWSMP.

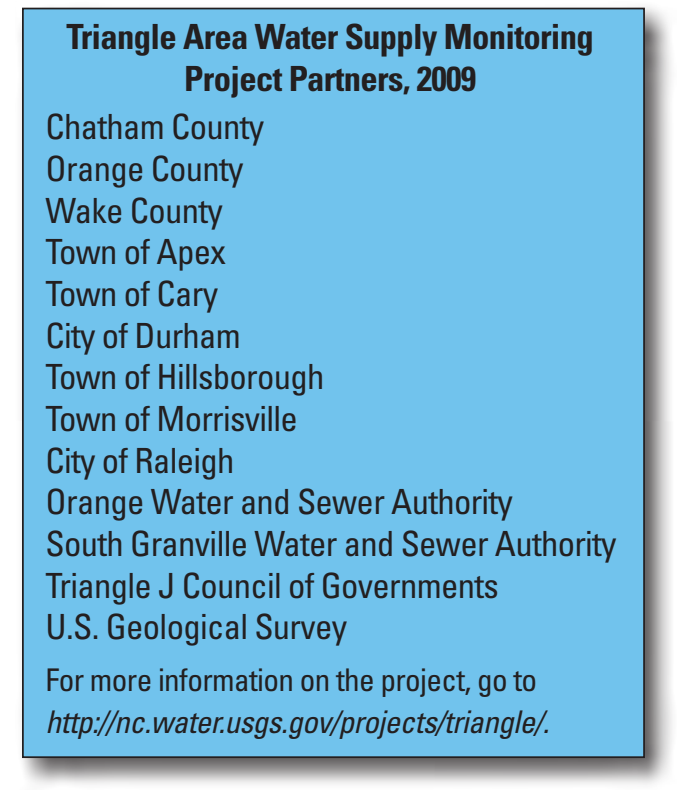

This report summarizes monitoring activities and data collected by the USGS for the TAWSMP during October 2008 through September 2009, also referred to as water year 2009. Hydrologic conditions in the Triangle area are described. Ranges of concentrations for water-quality field parameters, major ions, nutrients, metals and trace elements, chlorophyll a, organic carbon, and suspended sediment are presented for each site sampled during this period.

\section{Monitoring Network}

Since the project began in 1988, several adjustments have been made to sampling locations, sampling frequency, and constituents that are sampled. During 2009, the TAWSMP monitoring network comprised 31 sites, including streamgaging stations and stream and lake water-quality sites. Project sampling and analytical methods and quality-assurance practices are described by Oblinger (2004).

\section{Streamgaging Stations}

Streamflow records are useful for managing water supplies and are essential for determining in-stream loads of sediment, nutrients, and other constituents and interpreting water-quality trends. The USGS operates 10 continuous-record streamgaging stations that are funded through the TAWSMP (table 1). These gages report water level and discharge at 15 -minute intervals and display them in near-real time through the National Water Information System (NWISWeb) interface (http://waterdata.usgs.gov/ nc/nwis/current/?type $=$ flow) (U.S. Geological Survey, 2001a). Precipitation and streamflow data for several additional sites in the study area are available through other USGS programs.

\section{Water-Quality Sites and Constituents}

Water-quality data are used to track current conditions and to analyze long-term water-quality trends and pollutant loads in the Triangle area. The USGS monitored water quality at 26 sites in the TAWSMP study area during water year 2009. More than 7,000 individual measurements of water quality were made, not including lake vertical-profile data. The measurements were made at 15 sites in the Neuse River Basin and 11 sites in the Cape Fear River Basin. USGS water-quality data are available to project partners and the public via the NWISWeb (http://nwis.waterdata. usgs.gov/nc/nwis/qwdata) (U.S. Geological Survey, 2001c) or by request from the USGS North Carolina Water Science Center (http://nc.water.usgs.gov/) (U.S. Geological Survey, 2012d).

Nine public water-supply lakes were sampled, including Little River Reservoir, Lake Michie, Lake Butner, Falls Lake, Lake Wheeler, and Lake Benson in the Neuse River Basin, and Cane Creek Reservoir, University Lake, and Jordan Lake in the Cape Fear River Basin (table 1; fig. 1). Falls and Jordan Lakes are large, multipurpose reservoirs managed by the U.S. Army Corps of Engineers. The USGS sampled four sites at Falls Lake and four sites at Jordan Lake six times during water year 2009. The seven smaller reservoirs are used primarily for water supply; however, most also provide recreational access. One site in each of the seven smaller lakes was sampled four times during water year 2009. Vertical profiles of field parameters (water temperature, dissolved oxygen, specific conductance, and $\mathrm{pH}$ ) were measured, along with Secchi disk measurements of water transparency. Water samples were collected for analysis of alkalinity, nutrients, major ions (calcium, magnesium, sodium, potassium, chloride, fluoride, sulfate, and silica), iron, manganese, total and dissolved organic carbon, and chlorophyll $a$ during each sampling trip (Oblinger, 2004). Additional metals and trace elements (aluminum, arsenic, cadmium, chromium, cobalt, copper, zinc, lead, mercury, molybdenum, nickel, selenium, and silver) were sampled twice during the water year. 


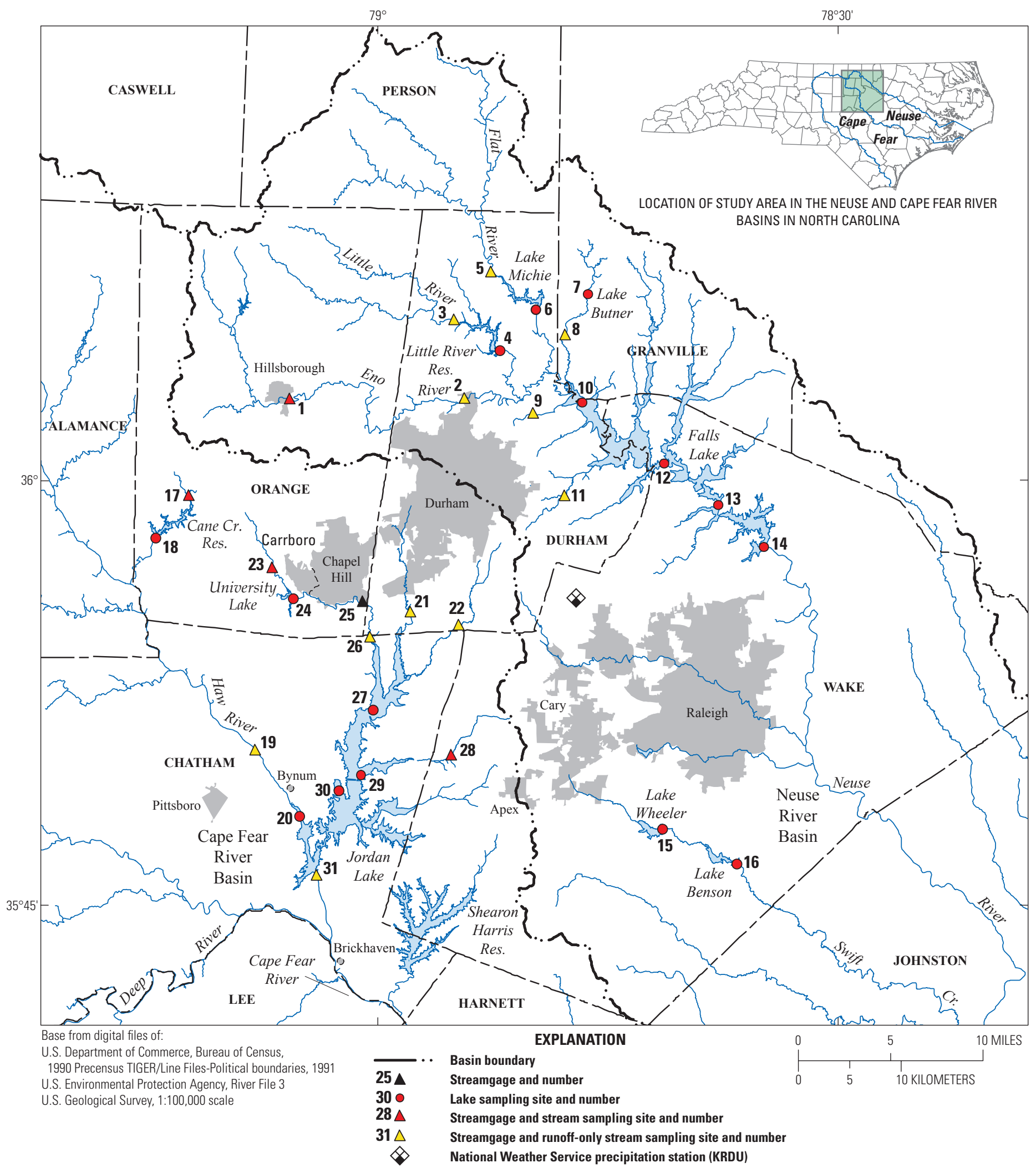

Figure 1. Location of Triangle Area Water Supply Monitoring Project data-collection sites in the upper Cape Fear and Neuse River Basins, North Carolina. 
Four stream sites were sampled by the USGS on a bimonthly basis for field parameters, nutrients, major ions, total and dissolved organic carbon, and suspended sediment, and twice for metals and trace elements. Seven additional stream sites were sampled by the USGS only during selected storm-runoff events to supplement data collected by the North Carolina Division of Water Quality (NCDWQ) Ambient Monitoring System. The 11 runoff-only stream sites in the TAWSMP network are not all sampled during every year. A project goal is to collect 16 runoff-event samples per year among the 11 sites; the actual number varies from year to year depending on whether targeted flow conditions occur.

Alkalinity was determined in the field at the time of sampling, using USGS standard methods (Rounds, 2012). Other chemical analyses were performed at the USGS National Water Quality Laboratory in Denver, Colorado. Suspended sediment samples were analyzed at the USGS Eastern Region Sediment Laboratory in Louisville, Kentucky.

During water year 2009, routine sampling of the 15 lake sites and the 4 bimonthly stream sites was conducted. Seven additional stream sites were sampled once or twice, resulting in a total of nine runoff-event samples. It is important to note that results for the seven streams sampled only during runoff events do not represent typical water-quality conditions for these streams.

\section{Quality Assurance}

Quality-control samples, including sampling-equipment blanks, sampling-vehicle blanks, field blanks, and replicate environmental samples, were collected and reviewed throughout the year to ensure that project data-quality objectives were met (Oblinger, 2004). Approximately 15 percent of the sample load consisted of quality-control samples.

A field blank collected in June 2009 had detectable concentrations of the following filtered constituents: cobalt, manganese, molybdenum, nickel, zinc, arsenic, and selenium. The blank water for this field blank was collected from the sampling equipment onsite and was processed, preserved, and transported under the same conditions as the environmental sample. A sampling-vehicle blank collected at the same time showed no signs of contamination; therefore, the detections in the field blank were attributed to inadequately cleaned sampling equipment or a contaminated filter because the sampling-vehicle blank is poured into bottles that remain open during processing of the environmental sample (U.S. Geological Survey, 2006). Manganese was the only one of the detected constituents that was measured in environmental samples in the June sample, and the field blank concentration (1.9 micrograms per liter $[\mu \mathrm{g} / \mathrm{L}]$ ) was negligible relative to environmental concentrations (see the Water Quality section). Therefore, no significant positive bias was shown. A subsequent field blank collected in August 2009 had no detections for any constituent, indicating that the contamination in June 2009 was an isolated event.

\section{Precipitation and Streamflow}

Precipitation measured at the Raleigh-Durham International Airport (KRDU; fig. 1) from October 2008 through September 2009 totaled 34.7 inches, which is approximately 20 percent below the long-term mean annual precipitation of 43.1 inches (fig. 2). The yearly total included more than 6 inches of rain that fell during March 2009; rainfall for 8 of the remaining 11 months was below average (State Climate Office of North Carolina, 2011b).

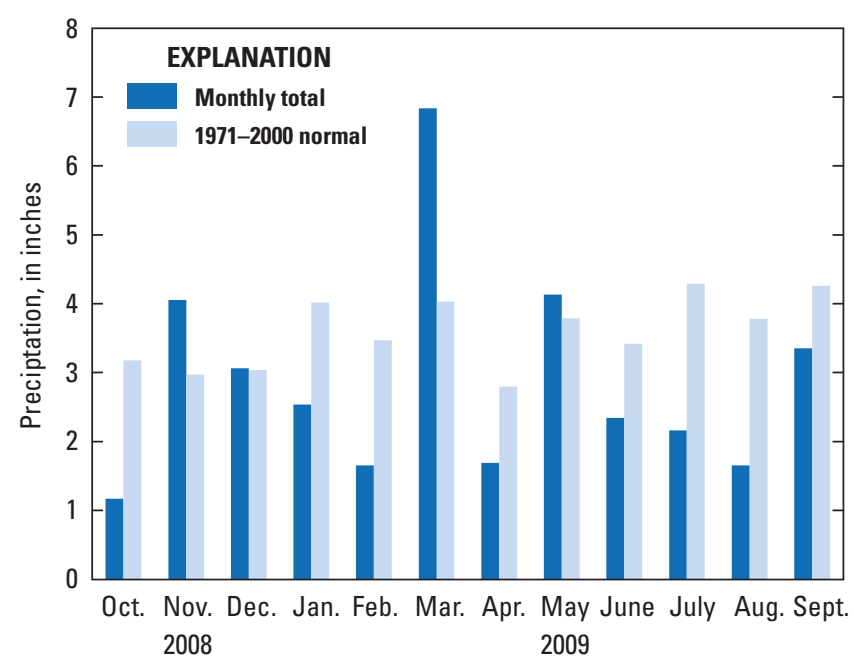

Figure 2. Monthly precipitation at the Raleigh-Durham International Airport, North Carolina (NOAA National Weather Service station KRDU), October 2008 through September 2009 (location in fig. 1. Source: State Climate Office of North Carolina (2011b)).

Another indication of hydrologic conditions is provided by the monthly Palmer Hydrological Drought Index scores for water year 2009 (fig. 3; State Climate Office of North Carolina, 2011a). This index reflects the long-term, cumulative impacts of drought on hydrologic characteristics, such as reservoir levels and streamflow. Negative values indicate dry periods, and positive values indicate wet periods. The Palmer Hydrological Drought Index defines 11 categories of wet and dry periods (Palmer, 1965). Among these categories, values greater than or equal to 4.00 are classified as extremely wet, values from 0.49 to -0.49 are considered to be near normal conditions, and values less than or equal to -4.00 are considered to be extreme drought conditions. The Palmer Hydrological Drought Index indicates that near normal to slightly wet conditions prevailed during October 2008 through June 2009 in the Northern Piedmont (including Orange, Durham, and Granville Counties). However, incipient drought conditions occurred in February 2009 and July 2009, with mild drought conditions seen in August 2009 and September 2009 in the same area. In the Central Piedmont (including Chatham and Wake Counties) of North Carolina (fig. 3), incipient drought conditions persisted in the area during most of the year, with the exception of June through July 2009 when wet conditions prevailed in the region. 


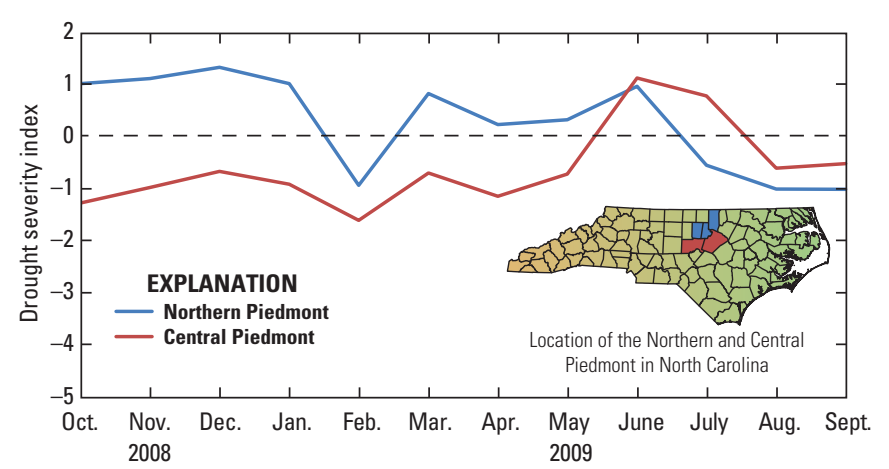

Figure 3. Palmer Hydrological Drought Index values for the Northern Piedmont and Central Piedmont climate divisions of North Carolina, October 2008 through September 2009. Values above zero indicate wet periods, and values below zero indicate dry periods. (Source: State Climate Office of North Carolina (2011a)).

Annual runoff is the total amount of water that is discharged, or that "runs off," from a watershed in 1 year. Runoff is computed as streamflow divided by watershed area and generally reported in inches. Due to evapotranspiration, groundwater inflow, and other losses, runoff reaching the stream accounts for a fraction of the total precipitation falling in the watershed. Annual runoff in 2009 was below long-term mean at all gaging stations (fig. 4), but not as low as during water year 2008 (Giorgino and others, 2012). The long-term mean is defined as the mean annual runoff for the period of record, which varies among stations (table 1). Annual runoff ranged from 6.78 to 19.12 inches among the 10 stations. At some sites, including New Hope Creek near Blands (site 21) and Northeast Creek near Genlee (site 22), a high percentage of the in-stream flow consists of treated effluent from municipal water reclamation facilities. These continuous inputs contribute to higher in-stream flows and mitigate the effects of drought on annual runoff (fig. 4).

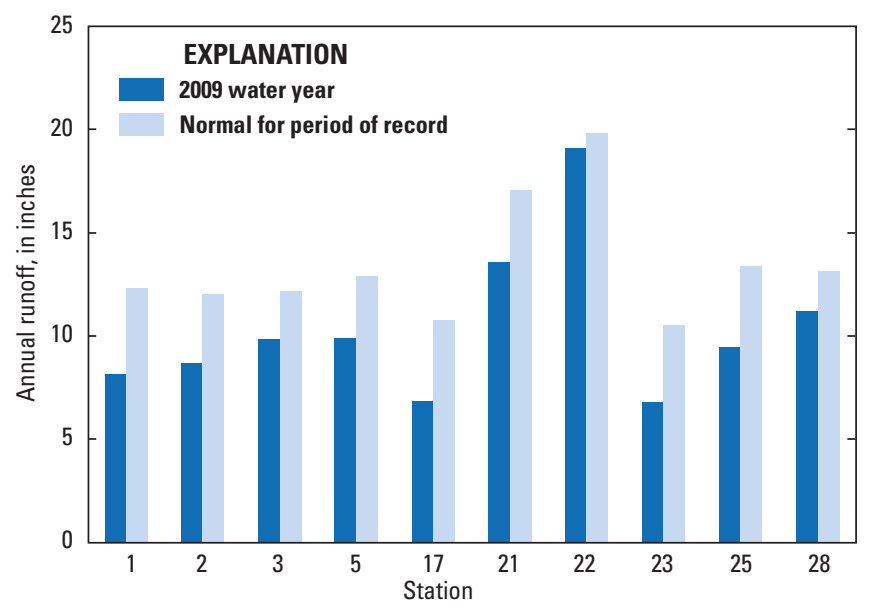

Figure 4. Annual runoff measured from October 2008 through September 2009 and the long-term mean runoff for the period of record at 10 streamgaging stations in the Triangle area of North Carolina. The period of record varies among stations (see table 1).
During most of water year 2009, streamflow conditions were generally within or just below the normal range, as illustrated by seven-day average streamflow hydrographs for Eno River at Hillsborough (site 1) in the Neuse River Basin and Haw River near Bynum (site 19) in the Cape Fear River Basin (fig. 5). Streamflow at both sites was above the long-term seven-day normal range during June 2009 (fig. 5). Three streams in the study area had periods of no flow during water year 2009 compared with five streams during water year 2008. No-flow periods occurred at Cane Creek near Orange Grove (site 17) and Morgan Creek near White Cross (site 23) during September 2009. During August 2009 through September 2009, White Oak Creek near Green Level (site 28) recorded several periods of no flow. Streamflow data collected at all 10 TAWSMP gaging stations were reviewed, quality assured, and published in the 2009 USGS Water Data Report (http://nc.water.usgs.gov/reports/WDR/) (U.S. Geological Survey, 2012b). Detailed data also are available online via the NWISWeb (http://waterdata.usgs.gov/nc/nwis/) (U.S. Geological Survey, 2001b).

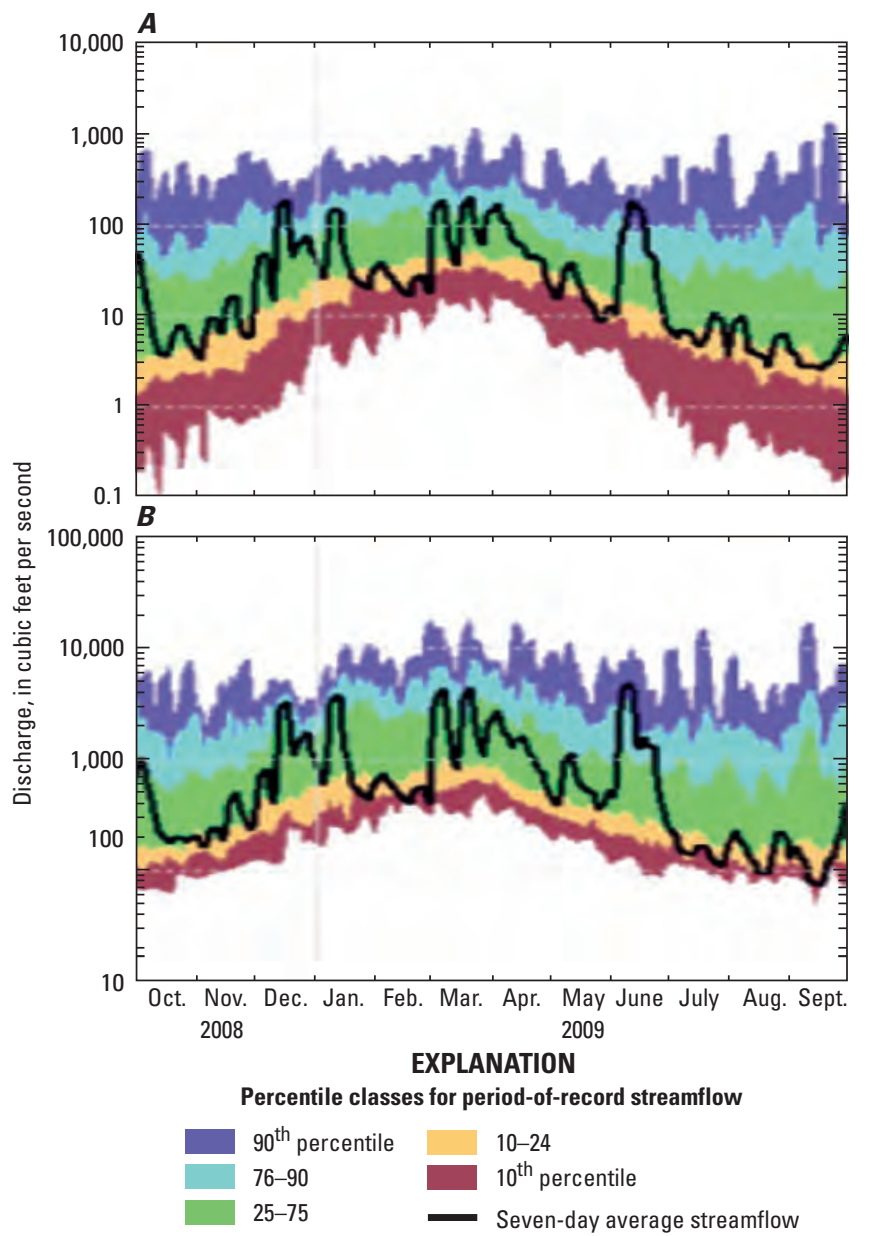

Figure 5. Seven-day average streamflow, in cubic feet per second, overlaid on period-of-record flow percentiles at (A) site 1, Eno River at Hillsborough in the Neuse River Basin; and $(B)$ site 19, Haw River near Bynum in the Cape Fear River Basin, for the period October 2008 through September 2009 (locations in fig. 1 and table 1). 


\section{Water Quality}

Water-quality data were reviewed, quality assured, and published in the USGS 2009 Water Data Report (http://nc.water.usgs.gov/reports/WDR/) (U.S. Geological Survey, 2012b). The data also are available online via the NWISWeb (http://waterdata.usgs.gov/nc/nwis/) (U.S. Geological Survey, 2001b). Ranges of concentrations observed at each site for 47 properties or constituents are presented (table 2). Although the USGS collects lake samples at multiple depths, only results from near-surface waters are summarized in this report. Additional data for lake samples collected at mid-depth or in near-bottom waters may be obtained from the NWISWeb or by request to the USGS North Carolina Water Science Center.

In-stream water-quality standards have been adopted by the North Carolina Division of Water Quality for 23 constituents monitored by the TAWSMP (table 2). All project sampling sites are in waters classified for water-supply use; therefore, applicable standards are the most stringent values established to protect freshwater aquatic life, water supply, or human health (North Carolina Department of Natural Resources, Division of Water Quality, 2007). Concentration ranges that are shown in table 2 in bold font indicate that at least one sample for the constituent exceeded a North Carolina water-quality criterion at that location. Water-quality exceedances occurred at 13 sites in the Neuse River Basin and at 10 sites in the Cape Fear River Basin. Maximum Contaminant Levels (MCLs) and Secondary Drinking Water Regulations (SDWRs) have been established by the U.S. Environmental Protection Agency for 20 of the monitored constituents (http://www.epa.gov/safewater/ contaminants/index.html) (U.S. Environmental Protection Agency, 2012). These criteria are applicable only to treated potable water - not to raw water supplies - and are provided for reference.

No exceedances of State water-quality criteria were observed for 13 of the 23 constituents for which standards exist, including temperature, hardness, chloride, fluoride, sulfate, nitrate, arsenic, cadmium, chromium, lead, nickel, selenium, and $\mathrm{pH}$. Exceedances were observed for 10 water-quality constituents, including dissolved oxygen, dissolved oxygen percent saturation, chlorophyll $a$, filtered and unfiltered mercury, copper, iron, manganese, silver and zinc (table 2). Eno River at Hillsborough (site 1), Lake Butner (site 7), and New Hope Creek (site 21) were the only sites sampled during water year 2009 that had no exceedances of water-quality standards for the constituents that were measured.

Stream samples collected during runoff events contained more particulate material than samples collected during routine sampling events. Therefore, runoff samples had higher concentrations of suspended sediment, total ammonia plus organic nitrogen, total phosphorus, total organic carbon, and total recoverable aluminum, arsenic, iron, manganese, chromium, cobalt, lead, nickel, silica, and zinc than routine stream samples. In addition, filtered organic carbon, orthophosphate as phosphorus, nitrite as nitrogen, and sulfate statistically were significantly higher in runoff samples. Comparisons were based on the Wilcoxon rank test $(\mathrm{p}<0.05)$.

\section{Dissolved Oxygen, $\mathrm{pH}$, and Specific Conductance}

Dissolved-oxygen concentrations less than the State standard of 5 milligrams per liter $(\mathrm{mg} / \mathrm{L})$ were observed occasionally at four lake and two stream sites in the study area (table 2; fig. 6A). At Little River Reservoir, Lake Michie, and University Lake (sites 4, 6, and 24), dissolved-oxygen concentrations less than $4.0 \mathrm{mg} / \mathrm{L}$ were recorded in late October 2008 when the water column was uniformly mixed. In addition, low dissolved-oxygen concentrations were measured during August 2009 at University Lake and the upper end of Falls Lake (site 10). Other low dissolved-oxygen concentrations were observed during low-flow conditions in White Oak Creek (site 28; $2.3 \mathrm{mg} / \mathrm{L}$, October 17, 2008) and Morgan Creek near White Cross (site 23; $2.5 \mathrm{mg} / \mathrm{L}$, August 7, 2009).

Dissolved-oxygen concentrations are dynamic in lakes and rivers, fluctuating with temperature, atmospheric pressure, and biological activity. When dissolved oxygen in water is in equilibrium with the air, the water is considered saturated. Under certain conditions, algae and aquatic plants produce oxygen through photosynthesis more rapidly than can be equilibrated with the atmosphere, resulting in supersaturated conditions. Supersaturation is commonly observed in productive lakes, especially during summer months.

Dissolved-oxygen saturation values greater than 110 percent exceed the State dissolved-gases standard and were recorded at six reservoir sites during 2009 (table 2; fig. 6B). Dissolved-oxygen saturation values greater than 110 percent also were measured at Cane Creek near Orange Grove (site 17) on February 12, 2009, and April 27, 2009. All recorded $\mathrm{pH}$ values were within the State's acceptable range of 6.0 to 9.0 standard units.

Although no standard has been adopted for specific conductance, considerable variation was shown for specific conductance among sites. The highest specific conductance value of 304 microsiemens per centimeter $(\mu \mathrm{S} / \mathrm{cm})$ at 25 degrees Celsius was recorded at Jordan Lake, Haw River arm (site 20) on August 12, 2009. Lake Butner (site 7) had the four lowest specific conductance values ranging from $43 \mu \mathrm{S} / \mathrm{cm}$ to $56 \mu \mathrm{S} / \mathrm{cm}$ among the study lakes (table 2). In water year 2008, Lake Butner had the greatest water transparency; however, in water year 2009, Cane Creek Reservoir (site 18) had the greatest water transparency of 1.7 meters (m) on June 16, 2009. 

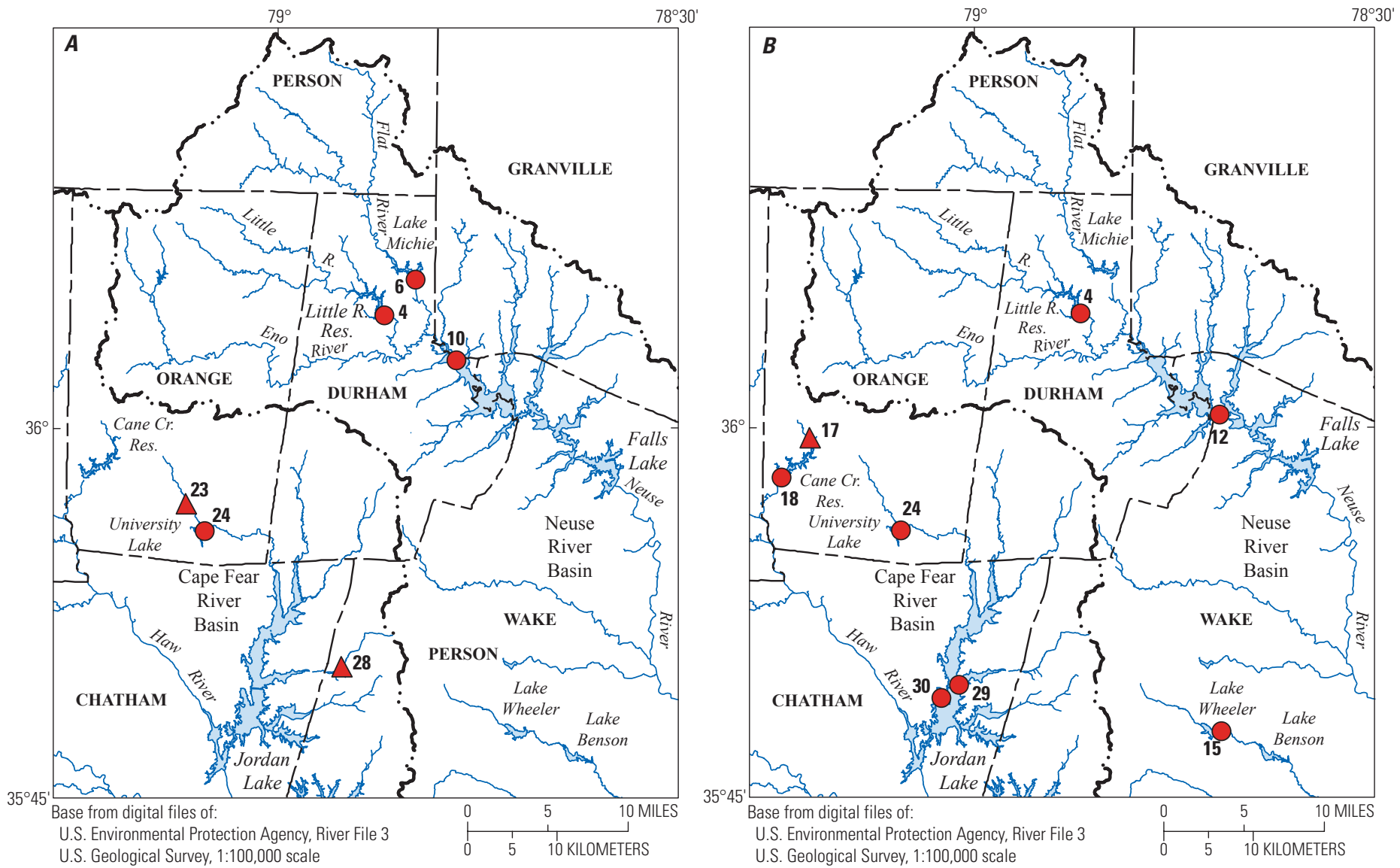

EXPLANATION

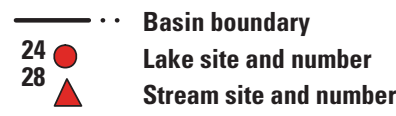

Figure 6. Sites in the Triangle area of North Carolina with one or more measurement of $(A)$ dissolved-oxygen concentration less than 5 milligrams per liter and $(B)$ dissolved-oxygen percent saturation values greater than 110 percent, 0 ctober 2008 through September 2009 (locations in fig. 1 and table 1). 


\section{Metals and Trace Elements}

Metals and trace element samples were collected twice per year at all stream and lake sites. In addition, iron and manganese were monitored at multiple depths during every lake sampling event.

The State aquatic-life standard for total recoverable iron is $1,000 \mu \mathrm{g} / \mathrm{L}$; however, the NCDWQ is proposing to eliminate this standard because iron occurs naturally in the State's waters (http://portal.ncdenr.org/web/wq/ps/csu/ swtrirev) (North Carolina Department of Environment and Natural Resources, 2010b). Iron concentrations exceeded $1,000 \mu \mathrm{g} / \mathrm{L}$ at seven streams and three lake sites in the study area during water year 2009 (table 2; fig. 7A). As in water year 2008, storm-related (runoff) stream samples consistently exceeded the standard in water year 2009. One routine sample collected at White Oak Creek near Green Level (site 28) exceeded the standard on April 29, 2009. Iron concentrations in lake surface samples were less than $1,000 \mu \mathrm{g} / \mathrm{L}$, except for those collected at Falls Lake at U.S. Interstate 85 (site 10), Jordan Lake, Haw River Arm (site 20), and University Lake (site 24; table 2). At the Falls Lake at U.S. Interstate 85, all six samples had concentrations above the standard; however, the standard for iron was exceeded only once at the other two sites listed above. Total recoverable manganese exceeded the $200 \mu \mathrm{g} / \mathrm{L}$ water-supply standard at eight lake sites and five streams sites during 2009 (table 2; fig. 7B). Iron and manganese tend to be substantially higher in lake bottom waters than near-surface samples during summer stratification as published in the 2009 USGS Water Data Report (http://nc.water.usgs.gov/reports/WDR/) (U.S. Geological Survey, 2012b).

Mercury samples were collected at all sites during water year 2009 as part of an ongoing, multiyear investigation of mercury in water and bed sediment. Higher concentrations of mercury in water generally were observed in lakes compared to streams. The one stream site that exceeded the $0.012 \mu \mathrm{g} / \mathrm{L}$ State standard for mercury during a runoff-event sampling was Ellerbe Creek near Gorman (site 9). Fourteen lake sites had total recoverable mercury concentrations above the State standard of $0.012 \mu \mathrm{g} / \mathrm{L}$ (table 2; fig. 7C); at 11 of those sites, filterable mercury also exceeded the standard at least once during water year 2009 (table 2). A maximum concentration of $0.497 \mu \mathrm{g} / \mathrm{L}$ total recoverable mercury was recorded at Jordan Lake at U.S. Highway 64 (site 29) on June 29, 2009. All mercury concentrations were less than the Federal drinkingwater MCL of $2 \mu \mathrm{g} / \mathrm{L}$.

Copper concentrations greater than the State waterquality action level of $7 \mu \mathrm{g} / \mathrm{L}$ were measured at Ellerbe Creek near Gorman (site 9) and Northeast Creek at SR 1100 (site 22). Both of these samples were collected in association with runoff events (table 2; fig. 7D). A maximum copper concentration of $13.2 \mu \mathrm{g} / \mathrm{L}$ was recorded at Ellerbe Creek (site 9) on January 6, 2009. This sample also contained the only zinc observation $(62.6 \mu \mathrm{g} / \mathrm{L})$ in excess of the State waterquality action level of $50 \mu \mathrm{g} / \mathrm{L}$ and the only silver observation $(0.148 \mu \mathrm{g} / \mathrm{L})$ in excess of the State water-quality action level of $0.060 \mu \mathrm{g} / \mathrm{L}$.

With the exception of aluminum, iron, lead, and manganese, all metal and trace element concentrations were less than Federal drinking-water MCLs or SDWRs (table 2) during 2009. As noted previously, MCLs and SDWRs are applicable to treated drinking water rather than untreated source water and are included for reference in this report. Aluminum, iron, and manganese occasionally exceeded SDWRs (table 2); however, concentrations were similar to those observed in the study area during previous years (http://nc.water.usgs.gov/reports/WDR/) (U.S. Geological Survey, 2012b). Lead exceeded the MCL of $15 \mu \mathrm{g} / \mathrm{L}$ (table 2) in one runoff sample collected at Ellerbe Creek near Gorman (site 9) on January 6, 2009, the same sample that exceeded water-quality standards for copper, zinc, and silver. 

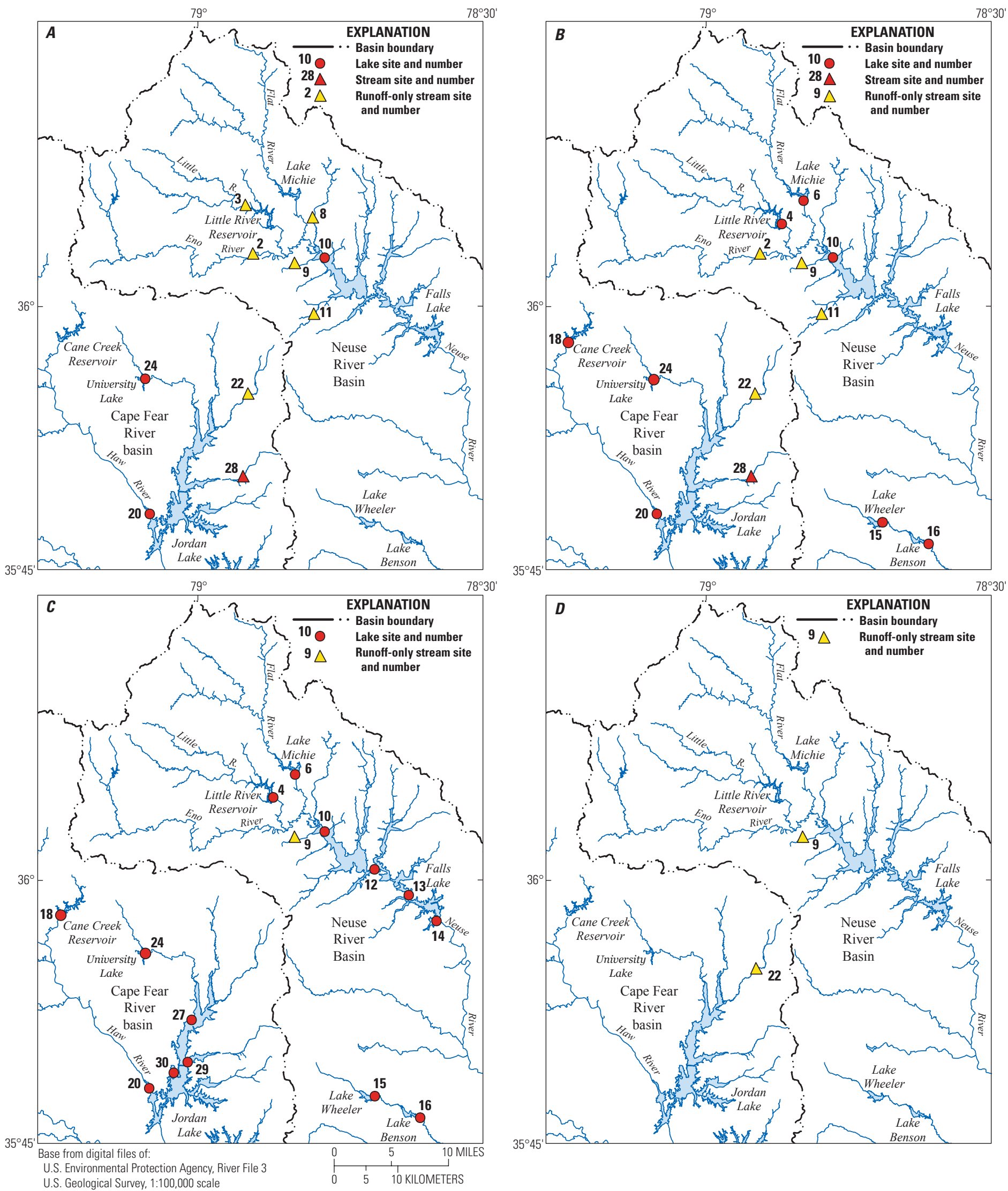

Figure 7. Sites in the Triangle area of North Carolina with one or more concentration of $(A)$ unfiltered iron greater than 1,000 micrograms per liter, $(B)$ unfiltered manganese greater than 200 micrograms per liter, $(C)$ unfiltered mercury greater than 0.012 microgram per liter, and (D) unfiltered copper greater than 7 micrograms per liter, October 2008 through September 2009 (locations in fig. 1 and table 1). 


\section{Chlorophyll a}

Chlorophyll $a$ was measured only at lake sites.

During water year 2009, concentrations greater than the North Carolina water-quality standard of $40 \mu \mathrm{g} / \mathrm{L}$ were observed at least once at 5 of the 15 lake sites, including Little River Reservoir, one site in Falls Lake, Cane Creek Reservoir, University Lake, and one site in Jordan
Lake (table 2; fig. 8). A maximum chlorophyll $a$ value of $71.2 \mu \mathrm{g} / \mathrm{L}$ was recorded at Jordan Lake at buoy 12 (site 27) on August 12, 2009. The North Carolina water-quality standard for chlorophyll $a$ was exceeded at this site two more times - during April and June 2009. As seen in water year 2008, Lake Butner (site 7) consistently had the lowest levels of chlorophyll $a$, with concentrations ranging from 3.0 to $6.1 \mu \mathrm{g} / \mathrm{L}$ in water year 2009 .

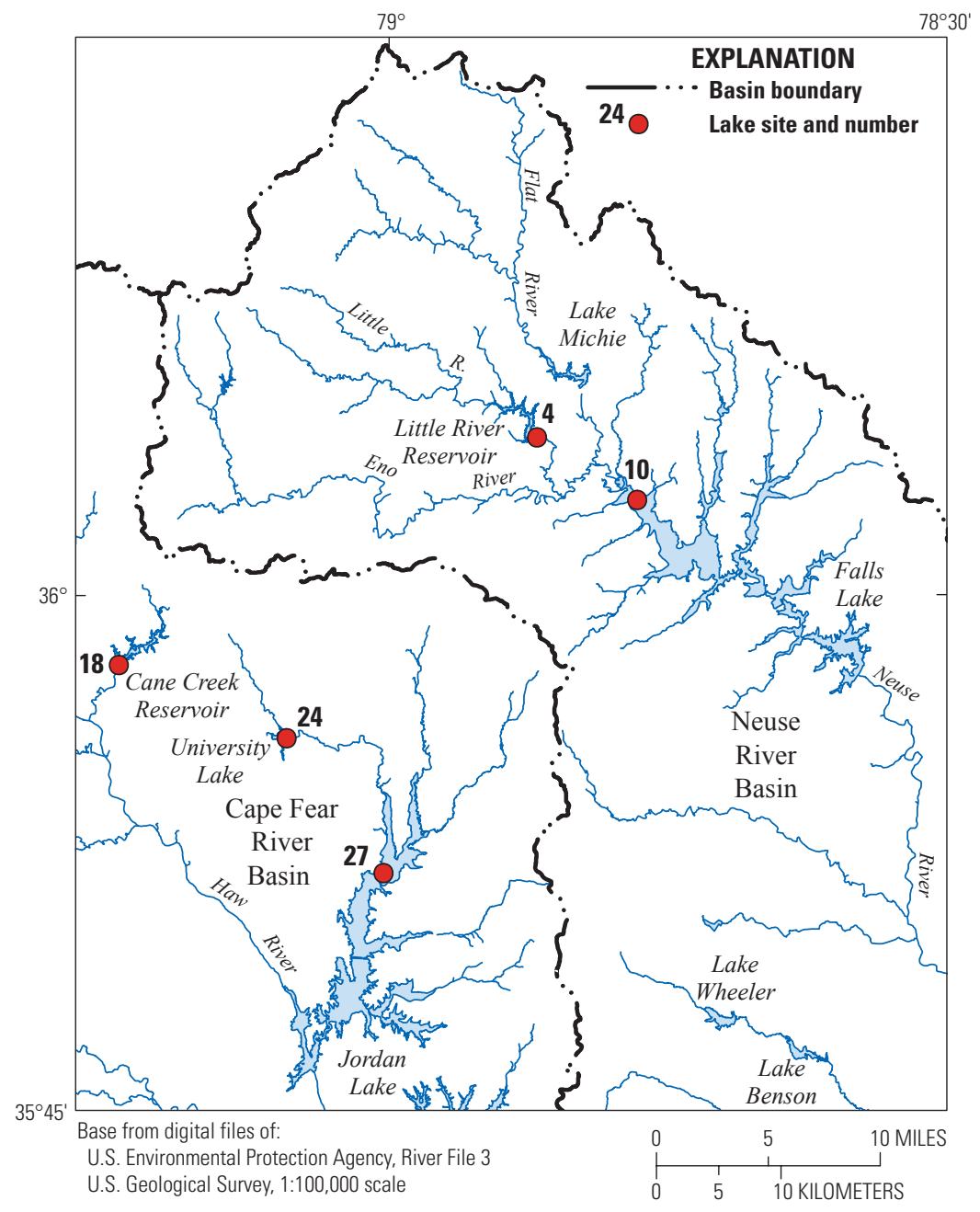

Figure 8. Sites in the Triangle area of North Carolina with one or more chlorophyll a concentration greater than 40 micrograms per liter, October 2008 through September 2009 (locations in fig. 1 and table 1). 


\section{Nitrogen and Phosphorus}

The USGS collected nutrient samples six times per year at four routine stream sites, four to six times per year at 15 lake sites, and during every sampling of seven runoff stream sites. Nutrient fractions that were analyzed included total ammonia plus organic nitrogen as nitrogen (also known as total Kjeldahl nitrogen), ammonia as nitrogen, nitrite as nitrogen, nitrate plus nitrite as nitrogen, orthophosphorus as phosphorus, and total phosphorus. A State water-quality standard exists only for nitrate plus nitrite $(10 \mathrm{mg} / \mathrm{L})$. The maximum observed concentration of nitrate plus nitrite was $2.41 \mathrm{mg} / \mathrm{L}$; consequently, the nitrate standard was never exceeded.

Nutrient concentrations were within ranges observed during previous years (http://nc.water.usgs.gov/reports/WDR/) (U.S. Geological Survey, 2012b). Total ammonia plus organic nitrogen concentrations ranged from $0.16 \mathrm{mg} / \mathrm{L}$ at Morgan Creek near White Cross (site 23) to $1.3 \mathrm{mg} / \mathrm{L}$ at Ellerbe Creek (site 9) and varied widely among sites and sampling dates (table 2). Nitrate plus nitrite concentrations ranged from near or below the reporting level $(0.016 \mathrm{mg} / \mathrm{L})$ at several lake sites to $2.41 \mathrm{mg} / \mathrm{L}$ at New Hope Creek (site 21; table 2). Total nitrogen values were computed by summing total ammonia plus organic nitrogen and nitrate plus nitrite. Among stream sites, New Hope Creek (site 21; fig. 9A) had the highest observed concentration of total nitrogen. Among lake sites, the highest concentrations of total nitrogen were observed at Falls Lake at U.S. Interstate 85, Jordan Lake Haw River arm, and Jordan Lake at buoy 12 (sites 10, 20 and 27, respectively; fig. $9 A)$.

Total phosphorus concentrations ranged from $0.013 \mathrm{mg} / \mathrm{L}$ at Morgan Creek near White Cross (site 23) to $0.53 \mathrm{mg} / \mathrm{L}$ at New Hope Creek (site 21) (table 2; fig. 9B). Except for the maximum concentration, all other samples were less than $0.4 \mathrm{mg} / \mathrm{L}$, and approximately 80 percent of samples were less than $0.1 \mathrm{mg} / \mathrm{L}$. Relatively higher concentrations (greater than $0.20 \mathrm{mg} / \mathrm{L}$ ) were recorded in storm-event samples from Ellerbe Creek, New Hope Creek, and Northeast Creek (sites 9, 21, and 22; fig. 9B). Lower concentrations (less than $0.05 \mathrm{mg} / \mathrm{L}$ ) were generally recorded at the four routine stream sites (Eno River at Hillsborough, Cane Creek near Orange Grove, Morgan Creek near White Cross, and White Oak Creek near Green Level), the seven small reservoirs (Little River Reservoir, Lake Michie, Lake Butner, Lake Wheeler, Lake Benson, University Lake, and Cane Creek Reservoir), three sites in Falls Lake (sites 12, 13, and 14), and two sites in Jordan Lake (sites 29 and 30; fig. 9B). Among lake sites, the highest concentrations of total phosphorus generally were observed at Falls Lake at U.S. Interstate 85, Jordan Lake Haw River arm, and Jordan Lake at buoy 12 (sites 10, 20 and 27; fig. 9B).

Concentrations of ammonia, nitrite, nitrate plus nitrite, and orthophosphorus were less than laboratory reporting levels in $60,47,36$, and 74 percent of samples. Most reportable concentrations were noted in streams throughout the year. As in previous years, lake sites generally had low concentrations of these dissolved, inorganic nutrient fractions near the water surface during summer months (June and August 2009) when nutrients tend to be taken up by phytoplankton. As seen in water year 2008, the somewhat riverine site 20, Jordan Lake Haw River arm, was an exception (Giorgino and others, 2012). Nitrate plus nitrite was above reporting levels during all six sampling events, ranging from 0.182 to $1.14 \mathrm{mg} / \mathrm{L}$ (table 2). Bottom-water concentrations of ammonia, orthophosphorus, and total phosphorus were higher than near-surface concentrations during the summer when lakes were thermally stratified. This was also consistent with results from previous years (http://nc.water.usgs.gov/reports/WDR/) (U.S. Geological Survey, 2012b). The highest concentrations reported in the study area for nitrate plus nitrite $(2.41 \mathrm{mg} / \mathrm{L})$, orthophosphorus $(0.454 \mathrm{mg} / \mathrm{L})$, and total phosphorus $(0.53 \mathrm{mg} / \mathrm{L})$ were observed on January 7,2009 , at New Hope Creek near Blands (site 21; table 2). 


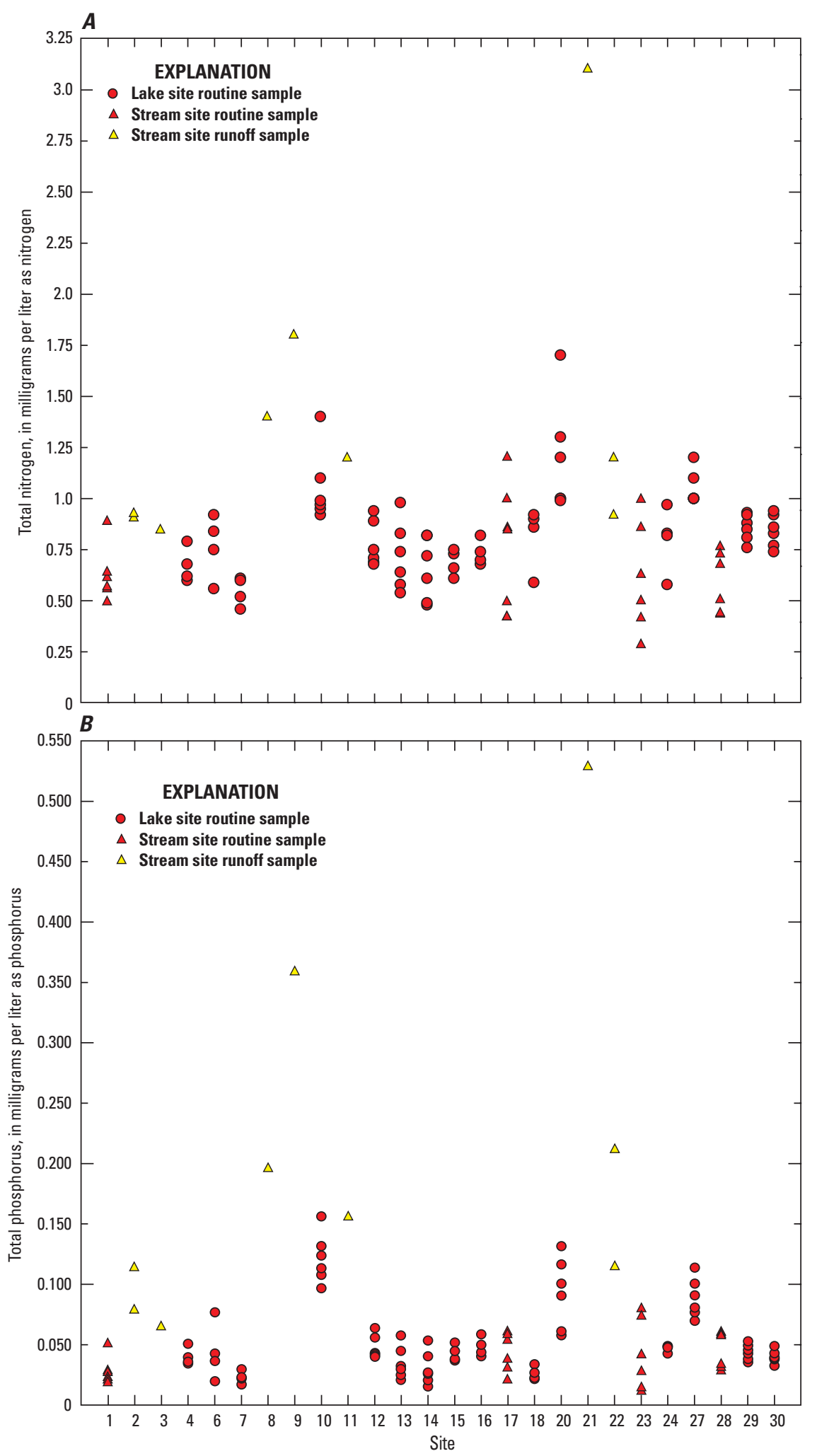

Figure 9. Concentrations of $(A)$ total nitrogen (ammonia plus organic nitrogen and nitrate plus nitrite) and $(B)$ total phosphorus at sites in the Triangle Area Water Supply Monitoring Project study area, October 2008 through September 2009 (locations in fig. 1 and table 1). 


\section{References}

Giorgino, M.J., Rasmussen, R.A., and Pfeifle, C.A., 2012, Quality of surface-water supplies in the Triangle area of North Carolina, water year 2008: U.S. Geological Survey Open-File Report 2012-1013, 12 p.

North Carolina Department of Environment and Natural Resources, Division of Water Quality [Division of Water Resources], 2010a, 2008 North Carolina integrated report categories 4 and 5 (impaired waters list), March 10, 2010: Raleigh, North Carolina, North Carolina Division of Water Quality, 139 p., accessed September 11, 2012, at http://portal.ncdenr.org/web/wq/ps/mtu/assessment.

North Carolina Department of Environment and Natural Resources, Division of Water Quality [Division of Water Resources], 2010b, Proposed changes to NC aquatic life standards for metals, March 2010: Raleigh, North Carolina, Environmental Management Commission, accessed on September 11, 2012, at http://portal.ncdenr.org/web/wq/ps/ csu/swtrirev.

North Carolina Department of Environment and Natural Resources, Division of Water Quality [Division of Water Resources], 2007, Surface waters and wetlands standards (May 1, 2007), NC Administrative Code 15A NCAC 2B: Raleigh, Environmental Management Commission, 134 p., accessed July 7, 2011, at http://portal.ncdenr.org/c/ document_library/get_file? unid=b399d1e0-0a9e-4dcc9605-a673d8a5c6df\&groupId $=38364$.

Oblinger, C.J., 2004, Triangle Area Supply Monitoring Project, October 1988 through September 2001, North Carolina-Description of the water-quality network, sampling and analysis methods, and quality-assurance practices: U.S. Geological Survey Open-File Report 2004-1278, $56 \mathrm{p}$.

Palmer, W.C., 1965: Meteorological drought: U.S. Weather Bureau, Research Paper No. 45, 58 p.

Rounds, S.A., 2012, Alkalinity and acid neutralizing capacity (ver. 3.0): U.S. Geological Survey Techniques of Water-Resources Investigations, book 9, chap. A6., sec. 6.6, September 2012, accessed May 17, 2013, at http://pubs.water.usgs.gov/twri9A6/.

State Climate Office of North Carolina, 2011a, Climate Division Data, accessed March 14, 2011, at http://www.nc-climate.ncsu.edu/climate/climdiv.php.

State Climate Office of North Carolina, 2011b, NC CRONOS database, accessed March 14, 2011, at http://www.nc-climate.ncsu.edu/cronos.
U.S. Environmental Protection Agency, 2012, Drinking water contaminants: U.S. Environmental Protection Agency, accessed September 11, 2012, at http://www.epa.gov/ safewater/contaminants/index.html.

U.S. Geological Survey, 2001a, National Water Information System (NWISWeb) - Current conditions for North Carolina [Streamflow]: U.S. Geological Survey database, accessed March 6, 2012, at http://waterdata.usgs.gov/nc/nwis/current/?type $=$ flow .

U.S. Geological Survey, 2001b, National Water Information System (NWISWeb) - USGS water data for North Carolina: U.S. Geological Survey database, accessed March 6, 2012, at $h t t p: / / w a t e r d a t a . u s g s . g o v / n c / n w i s /$.

U.S. Geological Survey, 2001c, National Water Information System (NWISWeb) - Water quality samples for North Carolina: U.S. Geological Survey database, accessed March 6, 2012, at http://nwis.waterdata.usgs.gov/nc/nwis/qwdata.

U.S. Geological Survey, 2006, Collection of water samples (ver. 2.0): U.S. Geological Survey Techniques of Water-Resources Investigations, book 9 , chap. A4, September 2006, accessed March 19, 2014, at http://pubs.water.usgs.gov/twri9A4/,

U.S. Geological Survey, 2012a, The Cooperative Water Program, accessed March 6, 2012, at http://water.usgs.gov/coop/.

U.S. Geological Survey, 2012b, Annual Water Data Report Series, accessed March 6, 2012, at http://nc.water.usgs.gov/reports/WDR/.

U.S. Geological Survey, 2012c, Triangle Area Water Supply Monitoring, accessed March 6, 2012, at http://nc.water.usgs.gov/projects/triangle/overview.html.

U.S. Geological Survey, 2012d, Water Resources of North Carolina, accessed March 6, 2012, at http://nc.water.usgs.gov/. 

For further information about this publication contact:

Director

U.S. Geological Survey

North Carolina Water Science Center

3916 Sunset Ridge Road

Raleigh, NC 27607

Or visit the North Carolina Water Science Center Web site at http://nc.water.usgs.gov/

Prepared by the Raleigh Publishing Service Center 
